\title{
Annotated checklist of the herpetofauna (Amphibia, Reptilia) of Lefkada Island (Ionian Islands, Greece)
}

\author{
Roberto Sindaco ${ }^{1 *}$, Roberta Rossi $^{1}$
}

\begin{abstract}
The island of Lefkada is a popular and easily accessible tourist destination; nevertheless, there is no comprehensive checklist of its interesting herpetofauna. Indeed, most records are old, scattered in different papers, and lacking precise locality data. In order to summarize the knowledge on the herpetofauna of the island, we critically reviewed literature, we looked for reliable records in the web and we carried out a field survey in May 2019.

The herpetofauna of Lefkada amounts to 28 species (six amphibians and 22 reptiles). The occurrence of Testudo graeca on the island is considered unlikely, while an additional species, Testudo marginata, is here reported based on web sources. Among the species recorded on the island, 25 have been recently confirmed, two of them (Rana dalmatina and Anguis graeca) over a century. For three species (Lissotriton graecus, Chelonia mydas, and Podarcis tauricus) the last records date back to over 30 years ago.
\end{abstract}

Key words: Amphibians, insular herpetology, Mediterranean islands, reptiles.

Riassunto - Checklist annotata dell'erpetofauna (Amphibia, Reptilia) dell'isola di Lefkada (Isole Ionie, Grecia).

L'isola di Lefkada è una rinomata meta turistica facilmente accessibile, ciononostante non esiste una checklist comprensiva sulla sua interessante fauna erpetologica. Infatti, la maggior parte delle segnalazioni è datata, dispersa in diverse riviste e priva di indicazioni sulle località di ritrovamento. Al fine di riassumere le conoscenze sull'erpetofauna dell'isola, è stata rivista criticamente la letteratura scientifica, sono stati cercati dati attendibili su internet e sono state condotte ricerche sul campo nel maggio 2019

L'erpetofauna di Lefkada è composta da 28 specie (sei anfibi e 22 rettili). La presenza di Testudo graeca sull'isola è considerata improbabile, mentre è riportata per la prima volta Testudo marginata, sulla base di informazioni disponibili sul web. Tra le specie presenti sull'isola, 25 sono state confermate in anni recenti, tra cui due, Rana dalmatina e Anguis graeca, a distanza di oltre un secolo dalla prima segnalazione. Per tre specie (Lissotriton graecus, Chelonia mydas e Podarcis tauricus) mancano conferme da oltre 30 anni.

Parole chiave: anfibi, erpetologia insulare, Isole del Mediterraneo, rettili.

${ }^{1}$ Via Fatebenefratelli 4, 10137 Torino, Italy.

E-mail: robertarossipg@gmail.com

* Corresponding author: rsindaco@gmail.com

(C) 2020 Roberto Sindaco, Roberta Rossi

Received: 23 September 2020

Accepted for publication: 28 October 2020

Online publication: 18 November 2020

\section{INTRODUCTION}

Lefkada is the fourth largest island of the Ionian Archipelago, with an area of $335.8 \mathrm{~km}^{2}$ (Fig. 1). It is connected to the mainland by a long causeway and a floating bridge. The island is mountainous (the highest point is Mount Stavrota, $1182 \mathrm{~m}$ a.s.l.), with few flat areas, mainly located near the coast. Hydrography is poorly developed, consisting of few, mostly temporary, streams. Freshwater bodies are scarce, with a single natural lake (Marantochori) and very few small artificial waterbodies. The climate is typically Mediterranean, characterized by hot summers with pronounced drought periods as well as humid and mild winters. Most of the rocks are limestones, with small areas of clay, sandstone, and flysch. The vegetation is luxuriant, although remodeled by centuries of agriculture and pasture, as shown by the abundant olive groves, shrubland and grazed garrigues, and the widespread presence of dry stone walls.

The herpetofauna of Lefkada is the least known among the main Ionian Islands, and an annotated checklist is not

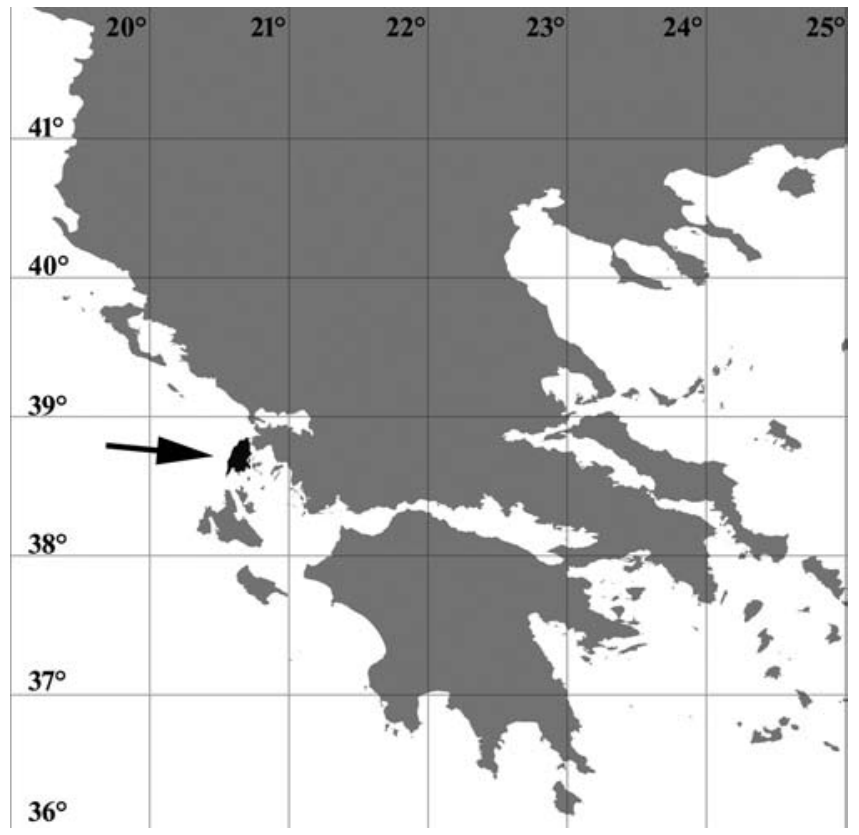

Fig. 1 - Position of Lefkada with respect to Greece. / Posizione di Lefkada rispetto alla Grecia. 
available. Indeed, most herpetological records of Lefkada are old and scattered in different papers; moreover, most of the records are generically referred to the island, lacking detailed locality data.

The first contribution on its herpetofauna (called with its ancient Venetian name "Santa Maura") is by De Betta (1868), who lists four species collected by A. Ninni and, erroneously, Discoglossus pictus. Werner (1894) found personally in "Santa Maura" nine species. Lehrs (1912) found on "Leukas" five species. Werner (1912) summarizes the knowledge on the herpetofauna of Ionian Islands, without adding original data. Werner (1929) reported on the findings made in 1926 and 1929 by M. Beier. Later Werner (1938) reports for the first time Hemidactylus turcicus, also collected on the island by M. Beier. Ondrias (1968), in its list of Greek amphibians and reptiles, reports for the first time Natrix natrix, without providing details on the source. In its monograph on Ionian Islands herpetofauna, Keymar (1986) quotes as "safe, proven occurrence" on "Levkas" six species of amphibians and 12 of reptiles, not adding original data. Chondropoulos $(1986,1989)$ summarizes the knowledge on Greek reptiles, and adds two new species to the island checklist, both based on personal observations. Broggi (1994) reports its personal findings made in 1986 and reports for the island 10 species, two of them new for the island. According to the maps by Valakos et al. (2008), five amphibians and 17 non-marine reptiles occur on the island. Recently Schmid (2019) reports on two field trips made in 2016 and 2018, and lists 15 species, not providing localities or dates.

The aim of this study is to summarize and update the knowledge on the Lefkada herpetofauna.

\section{MATERIALS AND METHODS}

In order to summarize the knowledge on the Lefkada herpetofauna, literature has been critically reviewed, as well as reliable information sources on the Web (citizen science portals, field-trip reports, pictures, forums etc.) documented by pictures and location. Moreover, the authors carried out a field survey in May 2019, spending nine days in surveying herpetofauna (14-26/5/2019). The different species were actively searched in suitable habitats (Visual Encounter Survey, VES) when active, or under logs and rocks, and along road transects by day and night. Species have been identified in the field, using the following field guides: Arnold \& Ovenden (2004), Valakos et al. (2008), Speybroeck et al. (2016).

Most of individuals were photographed (Figs. 2 and 3 ) and observations were recorded on the citizen science portal iNaturalist (www.inaturalist.org).

In the following list, for polytypic species trinomial nomenclature is adopted.

\section{RESULTS}

Overall, about 90 bibliographic records (but only 36 with location indication), 67 original (by the authors) and 105 citizen science records ( 75 with location indication) were collected. All data, comprehensive of chresonyms, localities, dates, observers/collectors, coordinates (and accuracy), references, and links are reported in the online Supplementary File. Distribution maps are shown in the Appendix 1, along with a species richness map on 1 by 1 $\mathrm{km}$ grid.

AMPHIBIA Linnaeus, 1758

CAUDATA Scopoli, 1777

SALAMANDRIDAE Goldfuss, 1820

Lissotriton graecus (Wolterstorff, 1906)

This newt was recorded by Werner (1894: 235) for "Santa Maura" and in two locations by Broggi (1994: 30) in 1986. Not reported ever since.

ANURA Duméril, 1805

BUFONIDAE Gray, 1825

Bufo bufo (Linnaeus, 1758)

Reported in literature only by Werner (1894: 234). We found a dead on road specimen near Agios Petros $(23 / 5 / 2019)$, and thousands of tadpoles in a pond south of Kalamitsi (25/5/2019) (Fig. 2A). There are several citizen sciences records from the following places: Apollonioi (15/2/2020 and 6/3/2019); Athani (7/9/2019); Marantochori (egg string; 12, 20 and 21/1/2019); Ponti Ag. Petrou (26/4/2019); Sivros (29/1/2019); Vasiliki (mating adults and tadpoles; 21/1/2019, 11/4/2019, 13/11/2019); Vournikas $(5 / 2 / 2019)$.

\section{Bufotes viridis (Laurenti, 1768)}

First reported in Lefkada by Werner (1929: 479) and then by Broggi (1994: 30) and Schmid (2019: 76).

Citizen science data are available from near Apollonioi $(16 / 9 / 2019,16 / 2 / 2020)$, Athani (4/11/2019), Ligia (12/4/2019) and Vasiliki (9/4/2019, 16/11/2019, $6 / 3 / 2020)$.

HYLIDAE Rafinesque-Schmaltz, 1815

Hyla arborea (Linnaeus, 1758)

Only reported in literature by Werner (1894: 234). We have heard some calls near Nydri (17/5/2019), and a chorus of several individuals at Marantochori lake $(25 / 5 / 2019)$. Reported in citizen science sites near Apollonioi (10/6/2019), Athani (6/6/2019) and Vasiliki (29/1/2019).

\section{RANIDAE Batsch, 1796}

\section{Rana dalmatina Fitzinger, 1838}

Only reported in literature by Werner (1929: 479). This old record is confirmed almost a century later by a citizen science record from near Apollonioi (25/1/2020), misidintified as Rana graeca.

Pelophylax kurtmuelleri (Gayda, 1940)

Only reported by Werner (1894: 234, 1929: 234). The authors found it at the Maranthochori lake (17/5/2019), in Nydri town (18/5/2019), at Nydri waterfalls (19/5/2019; Fig. 2B), at the Livadia reservoir (24/5/2019), north of Vasiliki (25/5/2019), and between Kortata and Kalamitsi $(25 / 5 / 2019)$. There are some citizen science records from near Apollonioi (7/11/2019), Marantochori (4/5/2019), and Vasiliki (16/4/2019, 26/9/2019). 
REPTILIA Laurenti, 1768

TESTUDINES Linnaeus, 1758

CHELONIIDAE Oppel, 1811

Caretta caretta (Linnaeus, 1758)

Lefkada is known to host some nesting sites of this turtle. Margaritoulis et al. (2003: 177) estimated 50
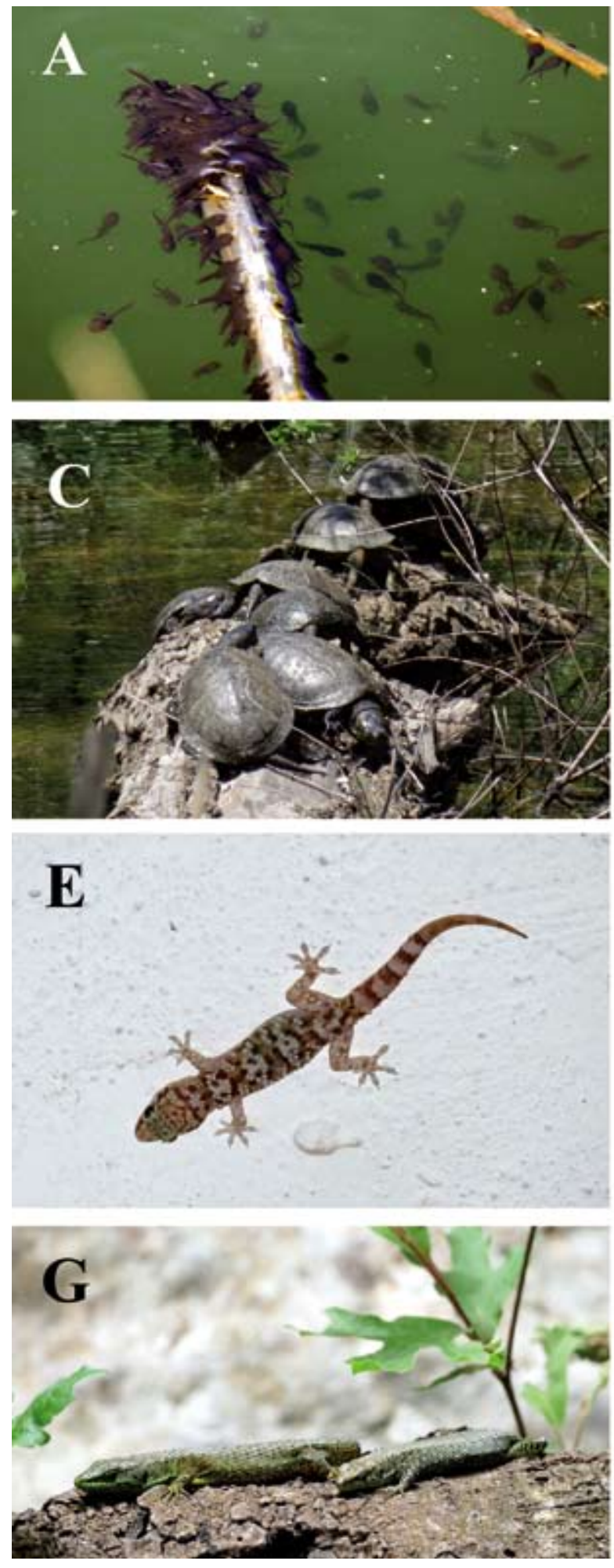

nests, while Vallianos \& Grimanis (2013: 5) estimated 15 nests on three beaches (Agios Ioannis, Mylos and Gialos). Some photos and videos of Loggerhead Turtles taken around Lefkada coasts are available on the web.
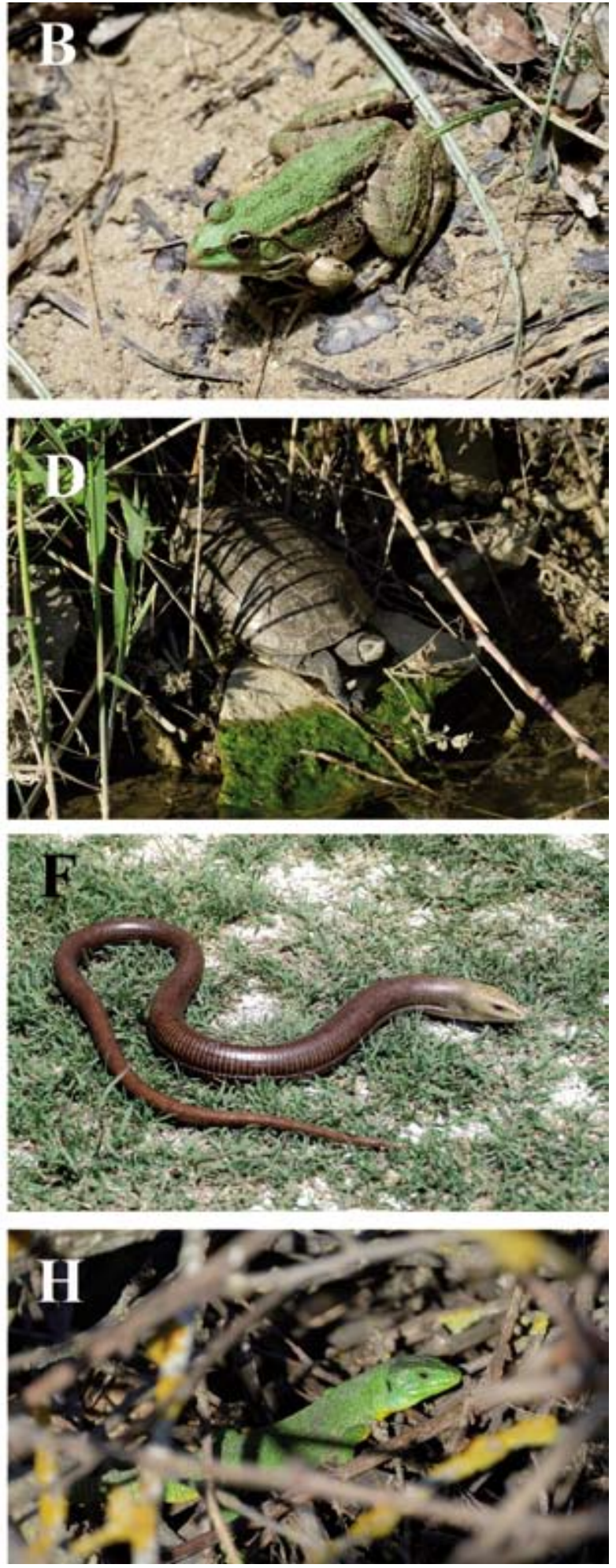

Fig. 2 - Herpetofauna observed by the authors on Lefkada. / Erpetofauna osservata dagli autori a Lefkada. A) Bufo bufo tadpoles. B) Pelophylax kurtmuelleri. C) Emys orbicularis. D) Mauremys rivulata. E) Hemidactylus turcicus. F) Pseudopus apodus. G) Algyroides nigropunctatus. H) Lacerta trilineata. 
Chelonia mydas (Linnaeus, 1758)

A stranded carcass was observed at Vasiliki beach (Broggi, 1994: 30).

EMYDIDAE Rafinesque-Schmaltz, 1815

Emys orbicularis (Linnaeus, 1758)

Emys orbicularis hellenica (Valenciennes, 1832)

The European Pond Terrapin was first reported on Lefkada by De Betta (1868: 892). Lehrs (1912: 449) found it "at several places". Fritz (1992: 75) examined two old museum specimens. Unexpectedly, recent records are missing both in literature and on the web. We observed at least 15 basking individuals along a stretch of the Maranthochori lake shore (17/5/2019; Fig. 2C) and two individuals in a small channel north of Vasiliki (25/5/2019).

GEOEMYDIDAE Theobald, 1868

Mauremys rivulata (Valenciennes, 1833)

The Balkan Terrapin is well known in Lefkada (De Betta, 1868: 893; Lehrs, 1912: 449; Fritz \& Wischuf, 1997: 257; Schmid, 2019: 76). We observed two adults in a small stream close to the sea inside Nydri town $(24 / 5 / 2019)$ (Fig. 2D). There are citizen science data from near Apollonion (29/3/2019, 27/7/2019) and Vasiliki $(26 / 1 / 2019,16 / 4 / 2019,14 / 3 / 2020)$.

TESTUDINIDAE Batsch, 1788

Testudo hermanni Gmelin, 1789

Testudo hermanni boettgeri Mojsisovics, 1889

Hermann's Tortoise was reported from Santa Maura (as $T$. graeca) by De Betta (1868: 890) and recently by Schmid (2019: 73). On the web there are two records of young specimen from Karya and Nydri, observed in October 2007, and two additional records with obscured coordinates, a carapace (5/9/2019) and an apparently captive individual $(25 / 4 / 2019)$.

\section{Testudo graeca Linnaeus, 1758}

The only source reporting the occurrence of this species in Lefkada is the map by Valakos et al. (2008: 184), possibly based on the old record of T. graeca by De Betta (1868: 890), reported by subsequent authors, which however refers to T. hermanni. Since Lefkada is far outside the range of this species and there are no evidences of the presence of this tortoise on the island, the occurrence of viable populations on Lefkada is unlikely.

\section{Testudo marginata Schoepff, 1792}

There are no literature data on the occurrence of this species on Lefkada. On the web there are some pictures by F. Trimigliozzi depicting marginated tortoises surviving a fire $(20 / 7 / 2003,5 / 8 / 2006)$. The presence of a viable population is suggested by the observation by F. Trimigliozzi of "twelve marginated tortoises emerging from a large hole dug on an embankment" (Forum Natura Mediterraneo, 2020). Other citizen science records from near Lefkada town (13/9/2010) and near Athani (26/4/2019) possibly refer to escaped specimens since the record from Lefkada town is in an urbanized area and the record from Athani is clearly a captive specimen. The origin of the population (native or man-mediated) is unknown.
SQUAMATA Merrem, 1820

GEKKONIDAE Oppell, 1811

Hemidactylus turcicus (Linnaeus, 1758)

The only literature record of the Turkish Gecko on the island is by Werner (1938). We observed two individuals on houses in Nydri town (25/5/2019; Fig. 2E). There are several citizen science records from near Agios Petros (11/4/2019), Apollonion (20/7/2019), Athani $(5 / 5 / 2019,30 / 9 / 2019)$, south of Athani (25/6/2019), Fryni $(24 / 9 / 2019)$, Kariotes (7/6/2019, 28/8/29019), Lefkada town (21/9/2019) and Vasiliki (19/11/2018, 3/5/2019, $6 / 11 / 2019)$.

ANGUIDAE Gray, 1825

Anguis graeca Bedriaga, 1881

The only record of the Greek Slow Worm from Lefkada is due to Werner (1894: 232). Its occurrence on the island is confirmed after over a century by a citizen science record from near Vasiliki (10/11/2019), where a dead specimen was photographed.

Pseudopus apodus (Pallas, 1775)

Pseudopus apodus thracius Obst, 1978

Available records of the Glass Lizard on Lefkada are scarce, both in literature (Werner, 1929: 474; Schmid, 2019: 72) and in the web: Ligia (17/6/2019) and Vasiliki (30/4/2019).

We found this species at several places: Agios Petros (17/5/2019), Komilio (23/5/2019), Livadia (24/5/2019), between Asprogerakata and Apolpaina (24/5/2019), Poros (25/5/2019), and Spanochori (26/5/2019; Fig. 2F).

\section{LACERTIDAE Batsch, 1788}

Algyroides nigropunctatus (Duméril and Bibron, 1839)

Algyroides nigropunctatus kephallithacius Keymar, 1986

The occurrence of the Dalmatian Algyroides in Lefkada is well known (Werner, 1894: 230; Werner, 1929: 477; Schmid, 2019: 73). We found this lizard at several localities: Marantochori (17/5/2019), Sivros (19/5/2019), Nydri waterfalls (19/5/2019, Fig. 2G), between Maranthochori and Kastri bay (23/5/2019), Fterno (23/5/2019), between Chortata and Kalamitsi (25/5/2019), Lefkada town (18/5/2019), Sivros (19/5/2019), Agios Ilias (19/5/2019), Agios Nikitas (24/5/2019), between Spanochori and Lefkas town $(24 / 5 / 2019$ and 26/5/2019), between Khortata and Kalamitsi (25/5/2019). Moreover, several citizen science records are available: Athani (18/9/2019, Frini (22/5/2019), Kariotes (2/6/2019), Karya (20/6/2019), Lefkada town (14/4/2019), Ligia (23 and 30/6/2019), Marantochori (24/7/2019), Sivros (2/6/2019), Vasiliki (28/8/2017, 8/3/2019, 2/4/2019, 6/5/2019).

\section{Lacerta trilineata Bedriaga, 1886 \\ Lacerta trilineata major Boulenger, 1887}

The Balkan Green Lizard was reported on Lefkada by Werner (1894: 230; 1929: 474) and Schmid (2019: 74). Also, citizen science records are scarce: Kariotes (20/6/2019) and Vasiliki (6/6/2019).

We observed this lizard at several places: Agios Petros (17/5/2019), between Charadiatika and Alatro (19/5/2019), 
Charadiatika (19/5/2019), Agios Ilias (19/5/2019), Fterno (23/5/2019), Pinakochori (24/5/2019), Agia Marina dunes W-NW of Lefkada town (24/5/2019), Livadia reservoir (24/5/2019), between Asprogerakata and Apolpaina $(24 / 5 / 2019)$, Sivros $(25 / 5 / 2019)$, between Sivros and Agios Petros (25/5/2019), between Chortata and Kalamitsi $(25 / 5 / 2019$; Fig. $2 \mathrm{H})$, north of Vasiliki (25/5/2019).

Podarcis tauricus (Pallas, 1814)

Podarcis tauricus ionicus (Lehrs, 1902)

The apparent absence of this lizard on Lefkada was already highlighted by Werner (1894: 229, 1929: 475), who stated that "on Santa Maura, despite my best efforts, I never found it anywhere". The only record is due to Broggi (1986: 30), who found this lizard near Vasiliki. After this record, there was no further observation apart from a doubtful citizen science record for the same locality, which deserves confirmation, as the quality of the image does not allow for a reliable identification.

The rarity of this species on Lefkada is surprising, since it is widespread on the other Ionian Islands (Psonis et al., 2017); it cannot be excluded that the occurrence in Vasiliki (a tourist site with ferry terminal from Cephalonia, where P. tauricus is common) is due to a human mediated introduction.

\section{SCINCIDAE Oppell, 1811}

Ablepharus kitaibelii (Bibron and Bory de Saint-Vincent, 1833)

The Snake-eyed Skink was recorded for Lefkada by Werner (1894: 232), Lehrs (1912: 449), and Poulakakis et al. (2005: 254). We observed three individuals in a stony pasture near Agios Ilias (19/5/2019) (Fig. 3A). There are also some citizen science data from near Kariotes (21/3/2020), Lefkada town (16/11/2019), and Marantochori (20/4/2019).

\section{TYPHLOPIDAE Merrem, 1820}

Xerotyphlops vermicularis (Merrem, 1820)

Until recently the Worm Snake on Lefkada was known only for a single specimen collected in 1929 by M. Beier (Werner, 1929: 478). Recently Schmid (2019: 75) reported on a second individual after about a century, unfortunately not providing information on the locality and date of the sighting, and not providing a picture.

\section{COLUBRIDAE Oppell, 1811}

Elaphe quatuorlineata (Bonnaterre, 1790)

The Four-lined Snake was first reported from the island by Schulz (1996: 213), not providing details on this finding. Later the species was also reported by Thanou et al. (2019: 103 and Supplementary material) and Schmid (2019: 73).

We found several individuals between Agios Petros and Komilio (17/5/2019), south of Maranthochori lake (17/5/2019, Fig. 3E), Agios Petros (17/5/2019), Sivros $(19 / 5 / 2019)$, Steno (S of Nydri) (19/5/2019), Athani $(23 / 5 / 2019)$. In addition, there are four citizen science records (April and May 2019), but their localities are not available since coordinates are obscured for threatened species.
Hierophis gemonensis (Laurenti, 1768)

The Balkan Whip Snake was first recorded on Lefkada by Chondropoulos (1989: 9), and then was reported by Broggi (1994: 32) and Schmid (2019: 72, 74). We found two dead on road adults near Vasiliki (19/5/2019) and near Marantochori (23/5/2019). Citizen science data are available from near Athani (18/7/2018), Ponti near Vasiliki (7/6/2019), and Vasiliki (3/9/2918).

\section{Platyceps najadum (Eichwald, 1831) \\ Platyceps najadum dahli (Schinz, 1833)}

The first record of $P$. najadum in Lefkada was reported by Schätti (2004: 529) and Schätti et al. (2005: 624) based on a shedded skin ("Häutung") preserved in the Geneva Museum (MHNG 2459.29). This record has been confirmed only recently by Schmid (2019: 73, 74, 75), who found another shedding and two individuals, not providing locality data. Therefore, no precise location is currently known, and the distribution map cannot be provided.

\section{Zamenis situla (Linnaeus, 1758)}

The first finding of the Leopard Snake dates back to 1985 (Broggi, 1994: 32). A dead on road specimen was observed in 2016 (Schmid, 2019: 74). A detailed record from Amousa (Ammouso) Bay (October 2007, K. Byrnes obs.) is also available on the web.

NATRICIDAE Bonaparte, 1840

Natrix natrix (Linnaeus, 1758)

Natrix natrix persa (Pallas, 1814)

First reported for "Leucade" by Ondrias (1968: 123), the Grass Snake is also reported in recent papers (Broggi, 1994: 32; Schmid, 2019: 73, 77). We found it near the Marantochori lake (23/5/2019, Fig. 3C) and between Kortata and Exantheia (26/5/2019). There is a single citizen science record from near Vasiliki (20/8/2018).

\section{Natrix tessellata (Laurenti, 1768)}

The Dice Snake is reported for Lefkada by several authors (De Betta, 1868: 927; Lehrs, 1912: 449; Broggi, 1994: 32; Schmid, 2019: 76). We did not find any individual during our survey, nor citizen science records.

PSAMMOPHIIDAE Boie, 1827

Malpolon insignitus (Geoffroy de Saint-Hilaire, 1827)

Malpolon insignitus fuscus (Fleischmann, 1831)

The Eastern Montpellier Snake has been reported by Chondropoulos (1989: 17), Broggi (1994: 32), and Schmid (2019: 74, 77). We found the species at seven localities: Agios Georgios monastery near Maranthochori(17/5/2019), between Maranthochori and the lake (17/5/2019; Fig. 3B), SW of Maranthochori (23/5/2019), south of Athani (23/5/2019), Livadia (24/5/2019), Vasiliki (25/5/2019), and Asprogerakata (26/5/2019). In addition, we found a single citizen science record from near Apollonioi (25/10/2019).

VIPERIDAE Oppell, 1811

Vipera ammodytes (Linnaeus, 1758)

Vipera ammodytes meridionalis Boulenger, 1903

The presence of the Nose Horned Viper in Lefkada is well known (Lehrs, 1912: 449; Broggi, 1994: 32; Schmid, 
2019: 74, 77). We found two dead on road adults, one south of Fterno (19/5/2019) and the other one south of Marantochori (23/5/2019, Fig. 3D). An additional record from near Apolpena (Apolpaina) $(8 / 5 / 2011)$ is available on the web.

\section{DISCUSSION AND CONCLUSIONS}

The present study provides the first annotated checklist on the herpetofauna of Lefkada Island (summarized in Tab. 1). According to the literature, its herpetofauna amounts to 28 species (six amphibians and 22 reptiles).
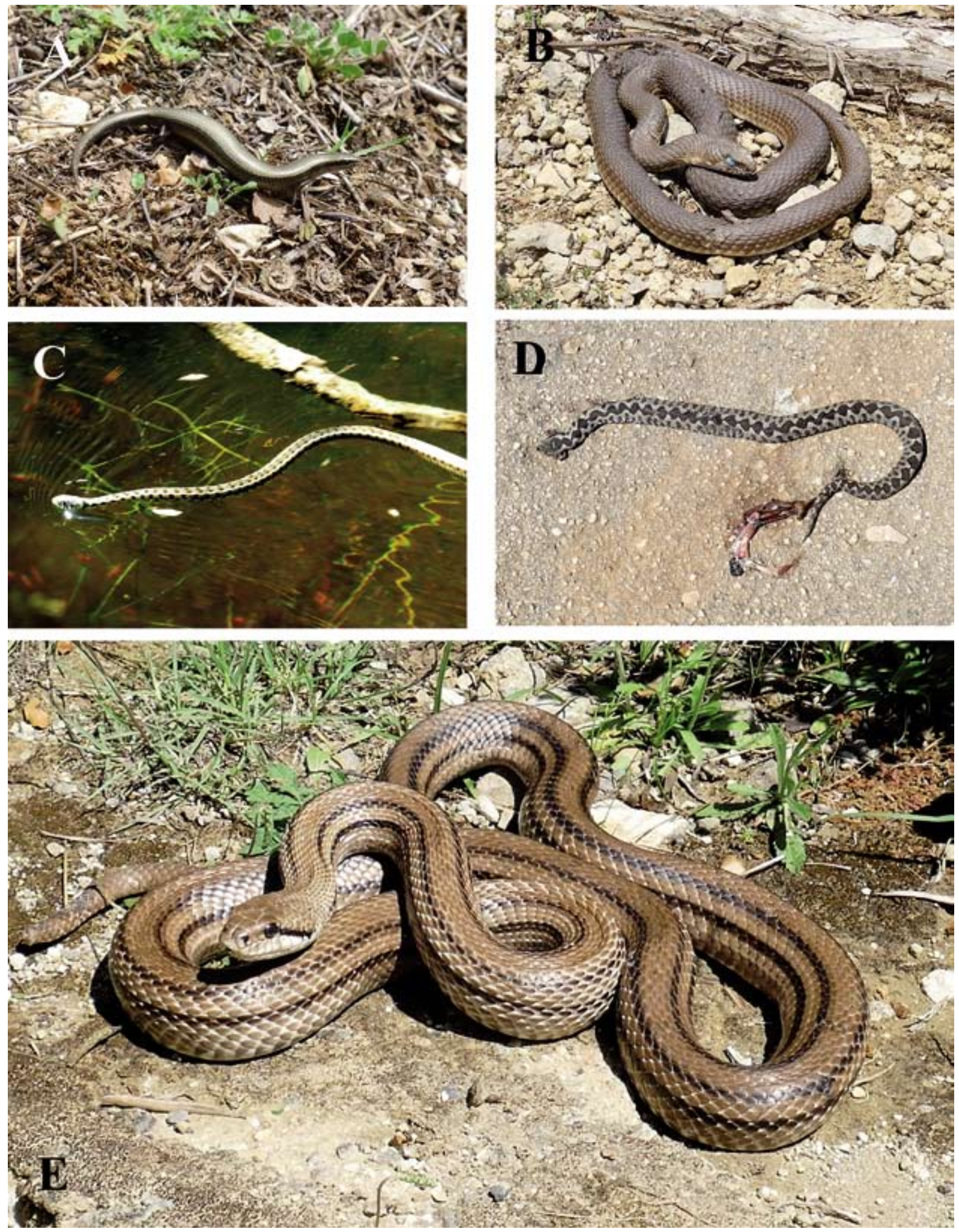

Fig. 3 - Herpetofauna observed by the authors on Lefkada. / Erpetofauna osservata dagli autori a Lefkada. A. Ablepharus kitaibelii. B. Malpolon insignitus. C. Natrix natrix. D. Vipera ammodytes. E. Elaphe quatuorlineata. 
An additional species, Testudo marginata, is here reported based on web sources (see Appendix 1). On the other hand, the occurrence of a population of T. graeca on the island is very unlikely, because of the lack of detailed data and the far distance from the species range in Greece; therefore, $T$. graeca is excluded from the Lefkada checklist.

The authors confirmed the occurrence of three amphibian and 12 reptile species during their survey and two additional taxa (Rana dalmatina and Anguis graeca) are confirmed by reliable citizen science observations after a century. Overall, also considering the recent literature, 23 out of 28 species recorded on the island are confirmed by very recent, reliable, and detailed data. For two species (Testudo marginata and Platyceps najadum) there are recent and reliable findings, but currently no precise location is known on the island. The last records of three species (Lissotriton graecus, Chelonia mydas, and Podarcis tauricus) date back to over 30 years ago.

In the citizen science site www.inaturalist.org is available a Podarcis muralis (Laurenti, 1768) record, a species never recorded on Lefkada, from Sivros (16/2/2019); the photograph seems to represent this species, but it is not sufficiently sharp to rule out that it is another lacertid, therefore the occurrence of $P$. muralis in Lekfada still needs to be demonstrated. Lastly, Oefinger \& Oefinger (2014), in a trip report published online, report on Tarentola mauritanica in Nydri (24/5/2014) without a picture; we consider the occurrence of this species as very doubtful.

The species richness map (Appendix 1, fig. 28) shows that most of the grids host just three or less species, sug-

Tab. 1 - Checklist of the herpetofauna of Lefkada Island, Greece, according to the main sources. Status: C = recently confirmed; $\mathrm{U}=$ present but not recently confirmed; $\mathrm{D}=$ doubtful. / Checklist dell'erpetofauna dell'isola di Lefkada, Grecia, secondo le fonti principali. Status: $\mathrm{C}=$ confermata di recente; $\mathrm{U}=$ presente ma non confermata di recente; $\mathrm{D}=$ presenza dubbia.

$*=$ only lizards and snakes are considered. $/ *=$ considerati solo serpenti e lucertole.

\begin{tabular}{|c|c|c|c|c|c|c|c|c|c|c|}
\hline $\mathbf{N}$ & Taxon & Status & $\begin{array}{l}\text { Werner } \\
(1929)\end{array}$ & $\begin{array}{c}\text { Keymar } \\
\text { (1986) }\end{array}$ & $\begin{array}{c}\text { Chondropoulos } \\
(1986,1989)^{*}\end{array}$ & $\begin{array}{c}\text { Valakos } \\
\text { et al. } \\
(2008)\end{array}$ & $\begin{array}{l}\text { Schmid } \\
\text { (2019) }\end{array}$ & $\begin{array}{c}\text { Other } \\
\text { literature } \\
\text { sources }\end{array}$ & $\begin{array}{c}\text { Authors } \\
\text { records }\end{array}$ & $\begin{array}{l}\text { Web } \\
\text { sources }\end{array}$ \\
\hline 1 & Lissotriton graecus & $\mathrm{U}$ & + & + & 1 & + & - & + & - & - \\
\hline 3 & Bufotes viridis & $\mathrm{C}$ & + & + & I & + & + & + & - & + \\
\hline 4 & Hyla arborea & $\mathrm{C}$ & + & + & I & + & - & + & + & + \\
\hline 6 & Pelophylax kurtmuelleri & $\mathrm{C}$ & + & + & 1 & + & - & + & + & + \\
\hline 7 & Caretta caretta & $\mathrm{C}$ & - & - & I & + & - & + & - & + \\
\hline 8 & Chelonia mydas & $\mathrm{U}$ & - & - & - & - & - & + & - & - \\
\hline 9 & Emys orbicularis hellenica & $\mathrm{C}$ & + & + & 1 & + & - & + & + & - \\
\hline 10 & Mauremys rivulata & $\mathrm{C}$ & + & + & 1 & + & + & + & + & + \\
\hline 14 & Anguis graeca & $\mathrm{C}$ & + & + & + & + & - & + & - & + \\
\hline 15 & Pseudopus apodus thracius & $\mathrm{C}$ & + & + & + & + & + & + & + & + \\
\hline 16 & $\begin{array}{l}\text { Algyroides nigropunctatus } \\
\text { kephallithacius }\end{array}$ & $\mathrm{C}$ & + & + & + & + & + & + & + & + \\
\hline 17 & Lacerta trilineata major & $\mathrm{C}$ & + & + & + & + & + & + & + & + \\
\hline 18 & Podarcis tauricus ionicus & $\mathrm{U}$ & - & - & - & + & - & + & - & $?$ \\
\hline 19 & Ablepharus kitaibelii & $\mathrm{C}$ & + & + & + & + & - & - & + & + \\
\hline 20 & Xerotyphlops vermicularis & $\mathrm{C}$ & + & + & + & + & + & - & - & - \\
\hline 21 & Elaphe quatuorlineata quatuorlineata & $\mathrm{C}$ & - & - & - & - & + & + & + & + \\
\hline \multirow[t]{2}{*}{28} & Vipera ammodytes meridionalis & $\mathrm{C}$ & + & + & + & + & + & + & + & + \\
\hline & TOTAL & & 17 & 18 & $12 *$ & 22 & 15 & 25 & 15 & 21 \\
\hline
\end{tabular}


gesting that the knowledge is still preliminary and further studies are needed to better know the distribution of different species on Lefkada. Indeed, little is known about the conservation status of the herpetofauna on the island, and particularly the tortoises and the wetland species (amphibians and terrapins). In fact, it is not surprising that two of the richer grids, accounting respectively 12 and 10 species, are respectively located around the tourist village of Vassiliki, while the third richer grid ( 8 species) includes one of the few wetland habitats of the island.

The detailed knowledge of the species distribution is necessary to protect the most relevant and threatened habitats, such as the breeding sites of amphibians or the places that host viable populations of tortoises and terrapins. Only a small surface of the island is protected by two habitat directive sites: the highest mountains by the "Periochi Chortaton" site (code GR2240002), and the northern lagoon and saltpans by the "Limnothalasses stenon Lefkadas (Palionis - Avlimon) kai Alykes Lefkadas" site (code GR2240001). These Natura 2000 sites do not protect most of the small wetland habitats of the island, such as the Lake Maranthochori, that host large populations of Emys orbicularis, Hyla arborea, Pelophylax kurtmuelleri and probably many other species.

To increase the knowledge on the species distribution, the citizen science can make a valuable contribution, provided that the sightings are carefully evaluated.

\section{Acknowledgements}

We thank the community of the citizen science site www.inaturalist.org, and the other web contributors, who considerably helped improving the knowledge on the herpetofauna of Lefkada Island. We also thank Alberto Venchi (Canberra, Australia) who kindly revised the manuscript before submission.

\section{REFERENCES}

Arnold E. N. \& Ovenden D. W., 2004 - Field guide to the Amphibians and Reptiles of Britain and Europe. Collins, London.

Broggi M. F., 1994 - Feldherpetologische Beobachtungen und Bemerkungen zu schützenswerten Biotopen auf griechischen Inseln (Amphibia; Reptilia; Griechenland). Herpetozoa, 7 (1/2): 29-34.

Chondropoulos B. P., 1986 - A check-list of the Greek reptiles. I. The lizards. Amphibia-Reptilia, 7: 217-235.

Chondropoulos B. P., 1989 - A checklist of Greek reptiles. II. The snakes. Herpetozoa, 2 (1/2): 3-36.

De Betta E., 1868 - I rettili ed anfibi della Grecia, con alcune notizie della distribuzione geografica delle specie. Atti regio Istituto veneto Scienze Lettere Arti, Venezia (3) 13 [1867-1868] (2): 876-963.

Forum Natura Mediterraneo, $2020-<\mathrm{https}$ ://www.naturamediterraneo. com/forum/topic.asp?TOPIC ID=18048> Accessed on: 2020-4-30.

Fritz U., 1992 - Zur innerartlichen Variabilität von Emys orbicularis (L. 1758). 2. Variabilität in Osteuropa und Redefinition von Emys orbicularis orbicularis (L., 1758) und E. o. hellenica (Valenciennes, 1832). Zoologische Abhandlungen Staatliches Museum für Tierkunde Dresden, 47 (5): 37-78.

Fritz U. \& Wischuf T., 1997 - Zur Systematik westasiatisch-südosteuropäischer Bachschildkröten (Gattung Mauremys). Zoologische Abhandlungen Staatliches Museum für Tierkunde Dresden, 49 (13): 223-260.

Keymar P. F., 1986 - Die Amphibien und Reptilien der Ionischen Region (Griechenland). Analyse ihrer rezenten Verbreitungs-muster und Überlegungen zu ihrer Ausbreitungsgeschichte. ÖHG $\mathrm{Na}$ crichten, Wien, 8/9: 8-44.
Lehrs P., 1912 - Reptilienleben auf Leukas. Verhandlungen der Gesellschaft Deutscher Naturforscher und Ärzte, 83 (2): 28-29.

Margaritoulis D., Argano R., Baran I., Bentivegna F., Bradai M.N., Camiñas J. A., Casale P., De Metrio G., Demetropoulos A., Gerosa G., Godley B. J., Haddoud D. A., Houghton J., Laurent L. \& Lazar B., 2003 - Chapter 11. Loggerhead turtles in the Mediterranean: Present knowledge and conservation perspectives. In: Loggerhead sea turtles. Bolten A. B. \& Witherington B. E. (eds.). Smithsonian Books, Washington D.C., 175-198.

Oefinger B. \& Oefinger P., 2014 - Lefkada, Kefalonia \& Akarnania, 24.5.-3.6.2014. $<\mathrm{https} / / /$ www.eurolizards.com/trip-reports/tripreports-before-2016/> Accessed on: 2020-5-8.

Ondrias J. C., 1968 - Liste des amphibiens et des reptiles de Grèce. Biologia Gallo-Hellenica, 1 (2): 111-135.

Poulakakis N., Lymberakis P., Tsigenopoulos C.S., Magoulas A., Mylonas M., 2005 - Phylogenetic relationships and evolutionary history of snake-eyed skink Ablepharus kitaibelii (Sauria: Scincidae). Molecular Phylogenetics and Evolution, 34: 245-256.

Psonis N., Antoniou A., Kukushkin O., Jablonski D., Petrov B., Crnobrnja-Isailovic J., Sotiropoulos K., Gherghel I., Lymberakis P. \& Poulakakis N., 2017 - Hidden diversity in the Podarcis tauricus (Sauria, Lacertidae) species subgroup in the light of multilocus phylogeny and species delimitation. Molecular Phylogenetics and Evolution, 106: 6-17.

Schätti B., 2004 - A preliminary contribution to Platyceps najadum (Eichwald, 1831) and systematic status of Coluber atayevi Tunijev and Shammakov, 1993 (Reptilia: Squamata: Colubrinae). Revue Suisse de Zoologie, 111 (3): 525-538.

Schätti B., Stutz A. \& Charvet C., 2005 - Morphologie, Verbreitung und Systematik der Schlanknatter Platyceps najadum (Eichwald, 1831) (Reptilia: Squamata: Colubrinae). Revue Suisse de Zoologie, 112 (3): 573-625.

Schulz K.-D., 1996 - A Monograph of the Colubrid Snakes of the genus Elaphe Fitzinger. Koeltz Scientific Books, Koenigstein.

Schmid A., 2019 - Ein Hörnchen zum Frühstück: Reptiliensuche auf Lefkada. Reptilia, Münster, 24 (136): 72-79.

Speybroeck J., Beukema W., Bok B., Van Der Voort J. \& Velikov I., 2016 - Field guide to the Amphibians and Reptiles of Britain and Europe. Bloomsbury, London and New York.

Thanou E., Kornilios P., Lymberakis P. \& Leaché A. D., 2019 - Genomic and mitochondrial evidence of ancient isolations and extreme introgression in the four-lined snake. Current Zoology, 66 (1): 99111.

Valakos E. D., Pafilis P., Sotiropoulos K., Lymberakis P., Maragou P. \& Foufopoulos J., 2008 - The amphibians and reptiles of Greece. Chimaira, Frankfurt am Main.

Vallianos N. \& Grimanis K., 2013 - Lefkada's sea turtle nesting lower than previously reported. British Chelonia Group Newsletter, 214: 4-5.

Werner F., 1894 - Die Reptilien- und Batrachierfauna der Jonischen Inseln. Verhandlungen der Zoologisch-Botanischen Gesellschaft in Wien, 44: 751-768.

Werner F., 1912 - Beiträge zur Kenntnis der Reptilien und Amphibien Griechenlands. Archiv für Naturgeschichte, 78A (5): 167-180.

Werner F., 1929 - Teil V. Reptilia, Amphibia, Orthoptera, Embidaria und Scorpiones. In: Zoologische Forschungsreise nach den Jonischen Inseln und dem Peloponnes. Beier M. (ed.). Sitzungsberichte der Kaiserlichen Akademie der Wissenschaften in Wien - mathematisch-naturwissenschaftliche Classe, 138 (9-10): 471-765.

Werner F., 1938 - Die Amphibien und Reptilien Griechenlands. Zoologica, Stuttgart, 35: 1-117+ 18 plates.

\section{SUPPLEMENTARY MATERIALS}

Tab. S1 - Dataset: Herpetological records of Lefkada Island / Dataset: segnalazioni erpetologiche per l'isola di Lefkada. 


\section{APPENDIX 1}

Maps of the herpetofauna of Lefkada. Black circle: original records by the authors. Triangles: records from citizen science. Circled dot: bibliographic data. No distribution map is provided for Platyceps najadum because no precise location is known at the present for the species on the island. / Carte di distribuzione dell'erpetofauna di Lefkada. Cerchio nero: dati originali degli autori. Triangoli: segnalazioni da Citizen science. Punto cerchiato: dato bibliografico. Non è presentata la carta di distribuzione di Platyceps najadum in quanto al momento non è nota alcuna località precisa di rinvenimento sull'isola.

1) Lissotriton graecus, 2) Bufo bufo, 3) Bufotes viridis, 4) Hyla arborea, 5) Rana dalmatina, 6) Pelophylax kurtmuelleri, 7) Caretta caretta, 8) Chelonia mydas, 9) Emys orbicularis, 10) Mauremys rivulata, 11) Testudo hermanni, 12) Testudo marginata, 13) Hemidactylus turcicus, 14) Anguis graeca, 15) Pseudopus apodus, 16) Algyroides nigropunctatus, 17) Lacerta trilineata, 18) Podarcis tauricus, 19) Ablepharus kitaibelii, 20) Xerotyphlops vermicularis, 21) Elaphe quatuorlineata, 22) Hierophis gemonensis, 23) Zamenis situla, 24) Natrix natrix, 25) Natrix tessellata, 26) Malpolon insignitus, 27) Vipera ammodytes, 28) species richness based on the European statistical 1 by $1 \mathrm{~km}$ grid (ETRS89 LAEA) (intervals: 1-3, 4-5, 6-7, 8-9, 10-12 species). / Ricchezza specifica calcolata sulla griglia statistica europea 1x1 km (ETRS89 LAEA). Intervalli: 1-3 specie, 4-5 specie, 6-7 specie, 8-9 specie, 10-12 specie.
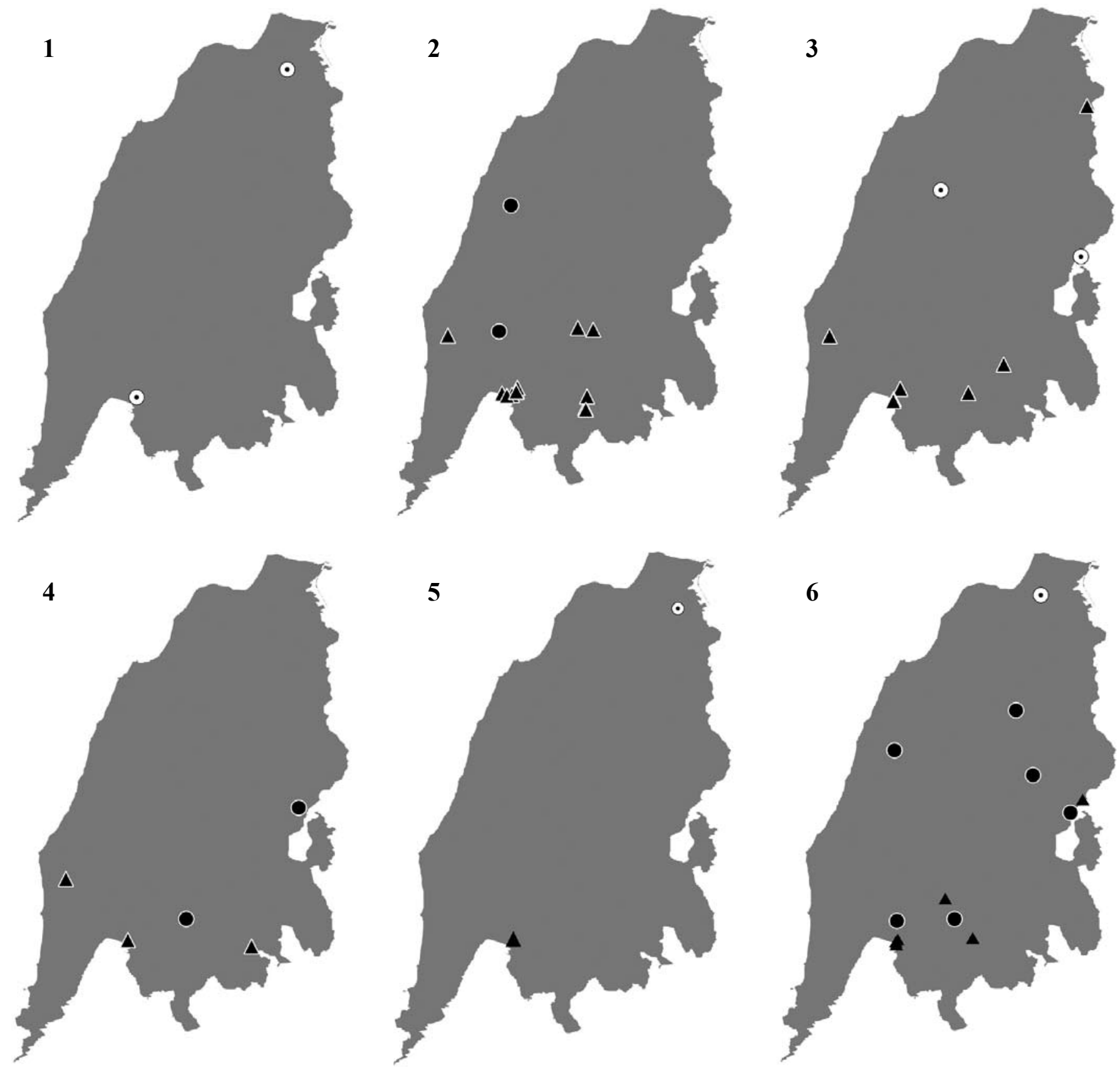

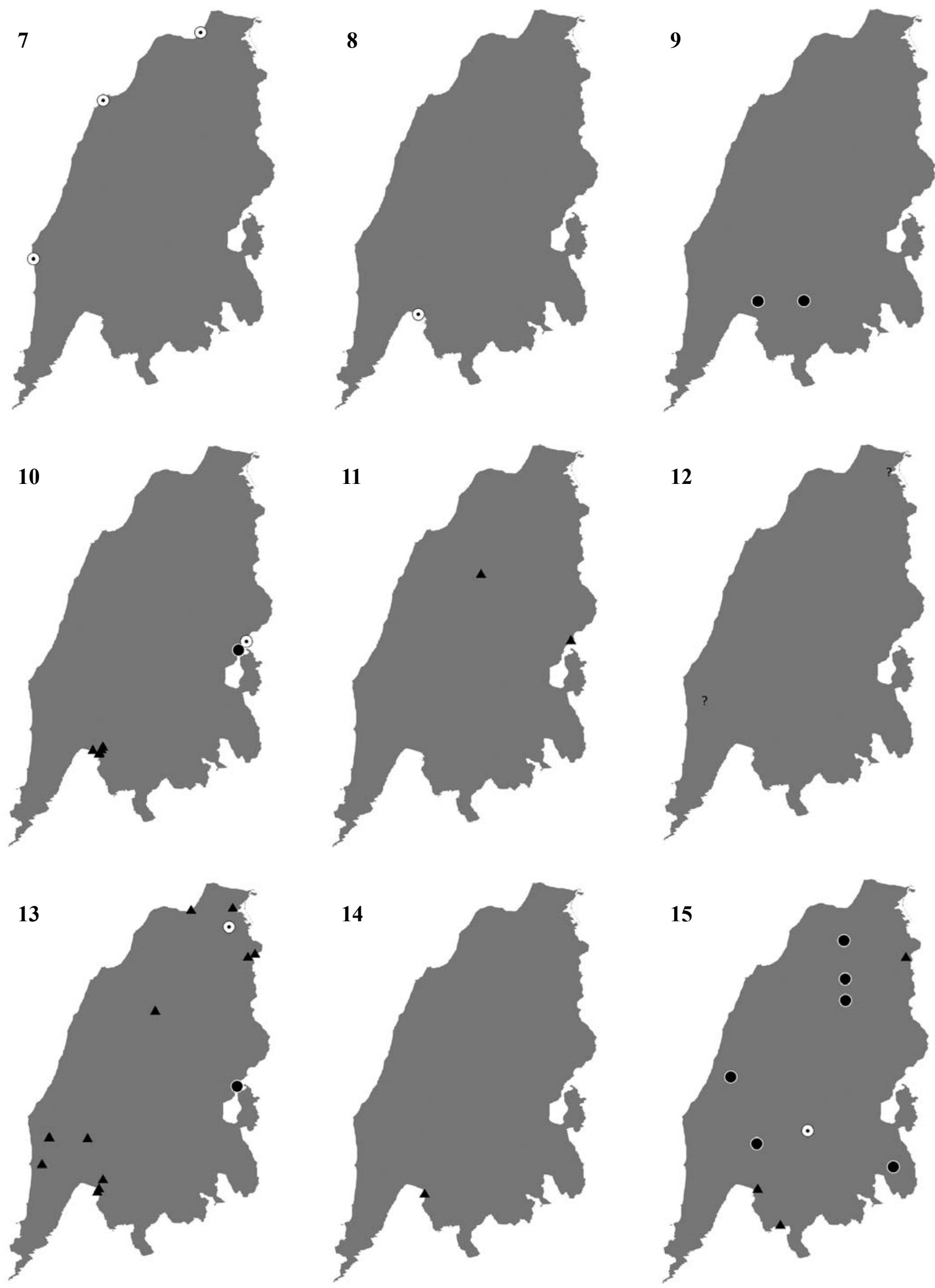

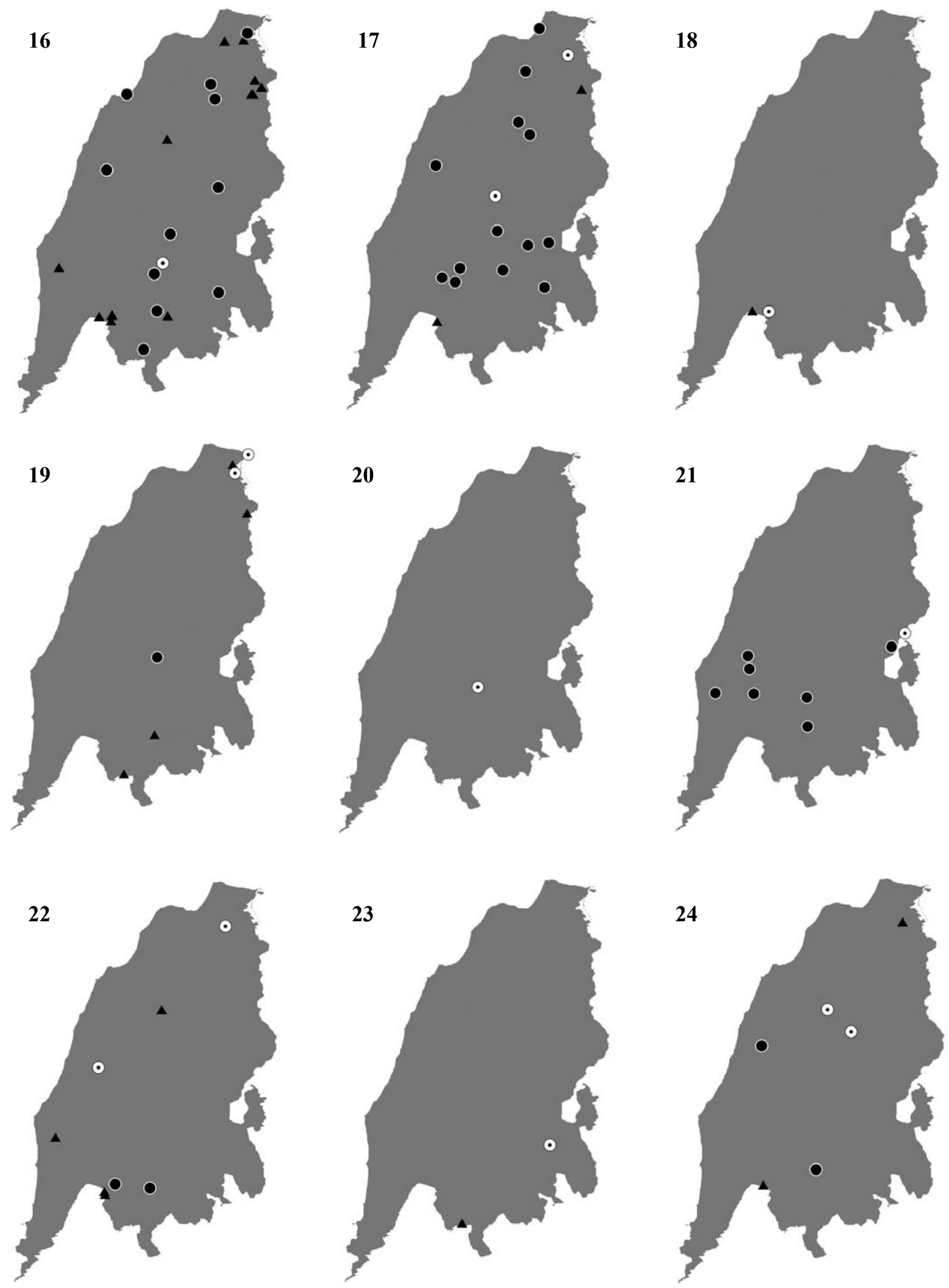

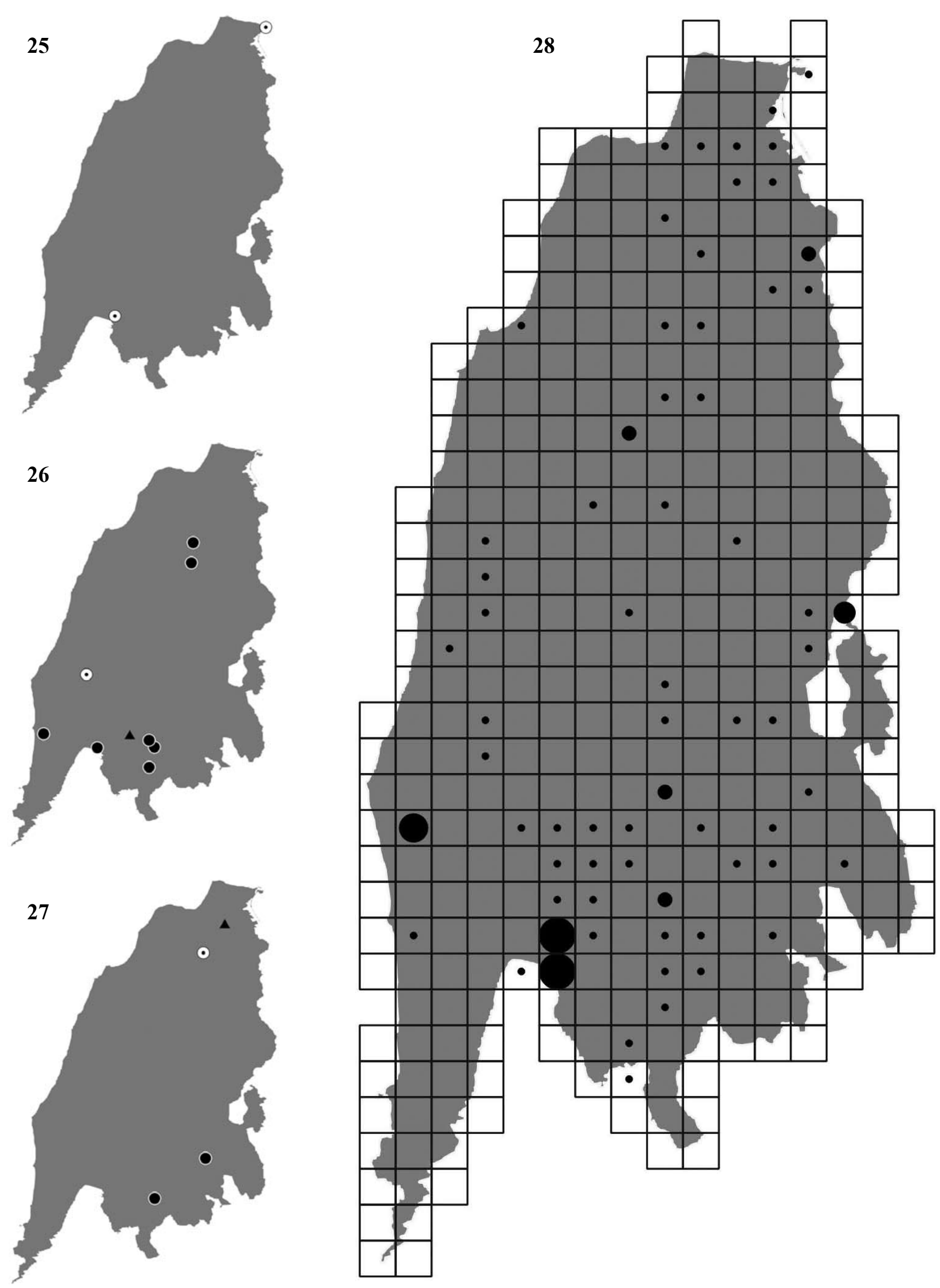